\title{
DAYA SAING PERANAN IPTEK DALAM PEMANFAATAN IKAN SIDAT BAGI KESEHATAN UNTUK PENINGKATAN MUTU SUMBER DAYA BAHARI
}

\author{
Martho Harry Melumpi* \\ *Dosen Fakultas Pertanian Program Studi Agribisnis Universitas Kristen Tentena \\ Email : harrymelumpi@ rocketmail.com
}

\begin{abstract}
Abstrak
Perikanan sidat merupakan aktivitas yang khusus dan penting, karena tidak semua wilayah perairan memiliki potensi ikan tersebut dan sidat adalah komoditas komersial dengan harga jual yang tinggi.Berbagai substansi bioaktif tersebut memiliki nilai farmakologis dan ekonomis yang tinggi sehingga perlu dilaksanakan penelitian secara berkelanjutan. Dari hasil penelitian yang dilakukan pada pengujian aktivitas antikoagulan dari ikan sidat spesis Anguilla marmorata menunjukkan aktivitas yang terbaik dapat memperlancar peredaran darah pada tubuh manusia dan kemajuan ilmu dan teknologi harus terus mencarai senyawa yang aktif dalam tubuh ikan sidat untuk dijadikan sebagai bahan baku farmasi dalam peningkatan kesehatan dan harapan hidup manusia. Dengan meningkatnya harapan hidup, makanan memainkan peran penting dalam mempertahankan kesehatan manusia.Hal ini merupakan tantangan bagi industri makanan karena konsumen tidak saja menuntut makanan yang lezat dan nikmat, tetapi juga sehat dan bergizi.Nutrasetik dari perairan merupakan pilihan rasional dan menarik untuk industri makanan karena sumber-sumber makanan dari organisme perairan laut maupun darat menyediakan berbagai komponen makanan fungsional yang dapat diperoleh darinya.
\end{abstract}

Kata Kunci : Daya saing, Pemanfaatan ikan sidat, Mutu sumber daya bahari

\begin{abstract}
Eel fishing is a special and important activity, because not all waters have the potential of fish and eel is a commercial commodity with a high selling price. Various bioactive substances have high pharmacological and economic values so that research needs to be carried out in a sustainable manner. From the results of research conducted on the testing of anticoagulant activity of Anguilla marmorata eel, the best activity can accelerate blood circulation in the human body and advances in science and technology must continue to find active compounds in the body of eels to be used as pharmaceutical raw materials in improving health. and human life expectancy. With increasing life expectancy, food plays an important role in maintaining human health. This is a challenge for the food industry because consumers not only demand delicious and delicious food, but also healthy and nutritious. Nutritics from the waters are a rational and attractive choice for the food industry because food sources from marine and terrestrial aquatic organisms provide various functional food components that can be obtained from them.
\end{abstract}

Keywords : Competitiveness, the use of eel, the quality of marine resources

\section{PENDAHULUAN [Times New Roman 11 bold]}

Pembangunan sektor kelautan dan perikanan sebagai sektor andalan utama pembangunan Indonesia merupakan pilihan yang sangat tepat.Hal ini didasarkan atas potensi yang dimiliki dan besarnya keterlibatan sumberdaya manusia yang diperkirakan hampir 12.5 juta orang terlibat di dalam kegiatan kelautan dan perikanan. Ikan merupakan sumber protein yang lebih baik dibanding hewan ternak karena rendahnya kandungan kolesterol dan relatif lebih murah.

Wilayah pesisir dan lautan Indonesia mempunyai kegunaan dan manfaat yang sangat besar bagi hidup dan kehidupan masyarakat Indonesia. Tingginya keanekaragaman hayati dilaut dapat 
merefleksikan potensi ekonomi perairan pesisir dan lautan tersebut, dalam arti bahwa semakin tinggi keanekaragaman hayati yang terkandung, semakin besar potensi yang dapat dikembangkan. Keanekaragaman hayati pesisir dan lautan diantaranya berguna sebagai sumber plasma nuftah, sumber pangan, bahan baku industri farmasi dan kosmetik, penyedia jasa-jasa lingkungan laut, serta pendukung untuk pengembangan kawasan industri dan pariwisata.

Indonesia merupakan negara maritim dengan lebih dari $70 \%$ permukaan buminya didominasi oleh lautan.Bahan alam bahari banyak dimanfaatkan dalam bidang pangan, industri, kesehatan, dan lingkungan yang umumnya bersumber dari organisme hayati. Banyak senyawa aktif yang diisolasi dari bahan alam bahari seringkali dapat menimbulkan efek mencolok terhadap organisme lain, sehingga menarik perhatian peneliti. Senyawa aktif tersebut dapat berupa bioaktif atau pun biotoksin (Soediro, 1998).

Perikanan sidat merupakan aktivitas yang khusus dan penting, karena tidak semua wilayah perairan memiliki potensi ikan tersebut dan sidat adalah komoditas komersial dengan harga jual yang tinggi.Berbagai substansi bioaktif tersebut memiliki nilai farmakologis dan ekonomis yang tinggi sehingga perlu dilaksanakan penelitian secara berkelanjutan. Berbagai bahan bioaktif (bioactive substances, natural product) yang terkandung dalam biota laut seperti omega 3 , hormon, protein, dan vitamin memiliki potensi yang sangat besar bagi penyediaan bahan baku industri farmasi dan kosmetik. Diperkirakan lebih dari 35.000 spesies biota perairan memiliki potensi menghasilkan bahan obat-obaatan, dan yang dimanfaatkan baru sekitar 5.000 spesies (Rokhmin, 2003).

Ikan seebagai sumber protein hewani merupakan bahan baku pangan utama yang berasal dari perairan. Protein yang berasal dari ikan bermanfaat untuk meningkatkan kesehatan, kecerdasan dan kesejahteraan masyarakat guna meningkatkan kualitas sumber daya manusia. Salah satu manfaat kesehatan dari ikan sidat adalah mempunyai kandungan asam lemak omega 3 tinggi. Omega 3 memiliki manfaat mengurangi resiko pembekuan darah. Omega 3 memiliki sifat antikoagulan sehingga peredaran darah menjadi lancar dan juga terhindar dari penyumbatan pembuluh darah.

Seiring dengan kecenderungan perubahan pola penyakit seperti adanya resistensi kuman penyakit pada obat tertentu, maka usaha penemuan obat-obat baru terus dilakukan dan saat ini penelitian cenderung dikembangkan ke laut karena sebagian besar sumber daya alamnya belum dieksploitasi secara maksimal (Caraan, 1994 dan Nybakken, 1993). Obatobatan alami merupakan hasil metabolit sekunder dari organisme hidup yang memiliki senyawa kimia khas. Senyawa hasil metabolit sekunder di organisme-organisme hidup merupakan unsur yang dipkai sebagai alat penangkal terhadap serangan penyakit dan mempertahankan hidup organisme tersebut. Senyawa metabolit sekunder ini lalu dikumpulkan, diproses dan dijadikan formula obat baru. Beberapa senyawa metabolit sekunder bio-organisme telah menjadi obat terkenal, seperti aspirin, morfin, digitalis, penisilin, dan taxol (Anonim, 2003)

Sidat (Anguilla sp) memiliki pola hidup katadromous yang artinya mengawali hidup di laut dalam, bertumbuh di perairan tawar, dan setelah matang kelamin akan kembali beruaya ke laut untuk memijah. Selain memiliki pola hidup yang unik, sidat juga populer sebagai makanan yang mewah karena memiliki nilai nutrisi yang baik. Meskipun perairan Danau Poso telah dikenal sebagai salah satu sentra produksi sidat, namun informasi ilmiah tentang keberadaan sidat dan tingkat pemanfaatannya belum banyak diungkapkan. Ikan sidat merupakan ikan endemik danau Poso. Ikan endemik adalah jenis ikan yang terdapat disuatu areal tertentu (sungai, danau, situs, pulau, negara, benua), (Limbong dkk 2012).

Menurut Sasongko dkk, (2007), bahwa sampai sekarang ikan sidat tak dapat dibudidaya oleh manusia, oleh karena itu nilainya sangat tinggi. Penelitian kedokteran moderen menemukan bahwa kandungan vitamin dan mikronutrien dalam ikan sidat sangat tinggi, di antaranya kandungan vitamin B1, vitamin B2, dan vitamin A masingmasing adalah 25 kali lipat, 5 kali lipat dan 45 kali lipat dari susu sapi, kandungan zinc merupakan 9 kali lipat susu sapi. Selain itu, (Napitupulu, 2011) ikan sidat juga memiliki manfaat kesehatan diantaranya adalah: 
1. Mengandung berbagai asam lemak tak jenuh yang tinggi yang tak ada pada hewan lainnya, sehingga dapat merupakan makanan utama yang memenuhi nafsu makan manusia, tanpa perlu kuatir badan akan menjadi gemuk. Rasa ikan sidat harum dan enak.

2. Memperpanjang umur dan melawan kelemahan dan penuaan tak ternilai. Sidat memiliki kandungan nutrisi protein, karbohidrat, serta omega 3 yang tinggi. Sehingga menguatkan fungsi otak dan memperlambat terjadinya kepikunan. Ikan sidat mempunyai kandungan asam lemak Omega 3 tinggi. Omega 3 ini dipercaya mampu meningkatkan fungsi mental, memori, dan konsentrasi manusia. Zat yang banyak terdapat dalam lemak sidat ini juga terbukti mampu mengobati depresi, gejala penyakit kejiwaan atau schizophrenia. Mengkonsumsi ikan sidat dapat mengatur imunitas tubuh manusia, sebagai antioksidan, menghilangkan racun tubuh, serta memperlambat penuaan.

4. Sudah banyak terbukti, mengkonsumsi ikan sidat secara teratur dapat mendorong terbentuknya lemak fosfat dan perkembangan otak besar, bermanfaat untuk meningkatkan daya ingat. Juga memperbaiki dan mempertahankan tekanan darah normal, mengobati pembuluh darah otak dan menurunkan kandungan lemak jahat dalam darah.

5. Banyak orang merasakan manfaat mengkonsumsi ikan sidat untuk penyakit rabun jauh, rabun dekat, glukoma dan penyakit mata kering di sebabkan karena mata terlalu lelah.

6. Minyak Ikan sidat dibuat dari ekstrak sum-sum ikan sidat segar, mengandung tiga jenis nutrient penting yaitu: asam lemak omega 3 EPA (eiscosapentaenoic acid) dan DHA (docosahexaenoic acid).

\section{METODE PENELITIAN}

Penelitian ini termasuk jenis penelitian studi literatur dengan mencari referensi teoro yang relefan dengan kasus atau permasalahan yang ditemukan.Referensi teori yang diperoleh dengan jalan penelitian studi literatur dijadikan sebagai fondasi dasar dan alat utama bai praktek penelitian ditengah lapangan.Data yang dikumpulkan terdiri dari data primer dan data sekunder.Data primer merupakan data yang diperoleh langsung dari lokasi penelitian yang melalui observasi, survey dan wawancara.Sedangkan data sekunder merupakan jenis data yang diperoleh dari studi kepustakaan dalam bentuk laporan dan publikasi.

\section{HASIL DAN PEMBAHASAN}

Ikan sidat Danau Poso mengandung berbagai asam lemak tak jenuh tinggi yang tidak terdapat pada hewan lainnya, sehingga dapat menjadi makanan utama yang meningkatkan nafsu makan manusia, tanpa perlu kuatir badan akan menjadi gemuk. Rasa ikan sidat harum dan enak, disebut sebagai ginseng air, yang berfungsi dalam memperpanjang umur, melawan kelemahan dan penuaan dini.

Penjaringan substansi bioaktif seperti antikoagulan sangatlah perlu dilakukan dan telah menjadi salah satu dasar untuk menemukan senyawa obat untuk mengatasi penyakit jantung dan stroke.Kandungan antikoagulan yang dikandung dari organisme perairan sangat bermanfaat dalam bidang kesehatan belum diupayakan.Hal ini dapat ditempuh dengan mencari sumber-sumber antikoagulan baru dari perairan kabupaten Poso yaitu ikan endemik Danau Poso sidat Anguilla marmorata.Protein merupakan suatu zat makanan yang sangat penting bagi tubuh karena selain berfungsi sebagai bahan bakar dalam tubuh juga berfungsi sebagai zat pembangun dan pengatur (Budiyanto, 2002).

Berkembanngya ilmu pengetahuan dan teknologi bahari saat ini memberikan manfaat bagi masyarakat. Hal ini memberikan keuntungan bagi daerah saya kabupaten Poso yang memiliki keanekaragaman sumberdaya perairan, salah satunya ikan sidat yang oleh masyarakat lokal Tentena menyebutnya dengan nama sogili atau masapi. Dewasa ini salah satu kebutuhan yang penting bagi manusia yaitu kesehatan.Seiring dengan kemajuan ilmu pengetahun dan teknologi dalam bidang kedokteran, semakin banyak jenis penyakit yang teridentifikasi.Oleh karena itu para ahli berusaha untuk mendapatkan substansi bioaktif yang dapat mengatasi masalah tersebut.Berdasarkan penelitian antikoagulan dari sidat Anguilla marmorata di perairan Kabupaten Poso 
Provinsi Sulawesi Tengah yang dilakukan oleh (Melumpi, 2015) mengatakan bahwa ikan sidat Danau Poso memiliki kandungan antikoagulan.Senyawa antikoagulan adalah senyawa yang mencegah terjadinya pembekuan darah pada manusia.

Dari hasil penelitian yang dilakukan pada pengujian aktivitas antikoagulan dari ikan sidat spesis Anguilla marmorata menunjukkan aktivitas yang terbaik yaitu pada menit ke 37 untuk ektrak metanol, Fraksi etil asetat menit ke 32 dan hasil kromatografi lapis tipis pada fraksi 3 menit ke 38 pada konsentrasi $0,0072 \mathrm{~g} / \mathrm{ml}$. Dengan demikian dapat disimpulkan bahwa ikan sidat yang dikenal memiliki berbagai khasiat kesehatan dapat digunakan sebagai obat antikoagulan yang bersumber dari alam dengan mengkonsumsinya dan tidak heran jika masyarakat di negara Jepang menjadikan makanana ikan sidat ini sebagai makanan yang mahal dengan khasiat kesehatan yang sangat tinggi untuk mengatasi berbagai penyakit.

Pada kenyataannya tidak semua produksi perikanan dapat dinikmati oleh masyarakat Indonesia, karena untuk beberapa jenis ikan memiliki pasar ekspor yang sangat baik, sehingga sebagian besar produksinya diekspor.Pada umumnya komoditas perikanan yang diekspor bila dipasarkan di pasar lokal harganya relatif mahal, sehingga tidak terjangkau bagi kebanyakan konsumen atau masyarakat Indonesia.

Dengan meningkatnya harapan hidup, makanan memainkan peran penting dalam mempertahankan kesehatan manusia.Hal ini merupakan tantangan bagi industri makanan karena konsumen tidak saja menuntut makanan yang lezat dan nikmat, tetapi juga sehat dan bergizi.Nutrasetik dari perairan merupakan pilihan rasional dan menarik untuk industri makanan karena sumbersumber makanan dari organisme perairan laut maupun darat menyediakan berbagai komponen makanan fungsional yang dapat diperoleh darinya.

Aplikasi bioteknologi memegang peranan ilmu pengetahuan dan teknologi dalam rangka menghasilkan produk bahan alami yang berasal dari perairan semakin meningkat dengan adanya kecenderungan kehidupan umat manusia untuk kembali ke alam (back to nature). Kecenderungan tersebut berkembang setelah kita sadar bahwa bahan-bahan yang terdapat di alam bila dipergunakan relatif lebih aman bagi kesehatan ketimbang bahanbahan sintesis.Pemikiran tersebut sangat beralasan karena produk yang dihasilkan oleh organisme perairan umumnya tidak menimbulkan efek samping dan bersifat terurai secara alamiah (biodegradable).Oleh karena itu, usaha-usaha yang dilakukan hendaklah diarahakan pada penelitian dan pengembangan makanan-makanan fungsional berbasis dari organisme perairan dengan prospek yang pada masa mendatang konsumsinya dapat menghasilkan penurunan prevalensi dan keparahan penyakit-penyakit kronis.

Dengan demikian program pemerintah ikan untuk ketahanan pangan dan gizi nasional dapat terwujud dalam meningkatkan kesejahteraan hidup serta kemakmuran bangsa dan negara. Jika anda berkunjung ke Kabupaten Poso belum lengkap rasanya jika belum menikmati keindahan Danau Poso dan menikmati kuliner ikan sidat yang memiliki manfaat kesehatan sebagai antikoagulan untuk memperlancar peredaran darah, disamping berwisata bahari dengan biaya yang murah anda juga akan mendapatkan kesehatan yang alami dan juga bagi Kabupaten Poso propinsi Sulawesi Tengah hal ini akan mendatangkan pendapatan daerah yang menguntungkan.

\section{KESIMPULAN}

Dengan meningkatnya harapan hidup, makanan memainkan peran penting dalam mempertahankan kesehatan manusia. Hal ini merupakan tantangan bagi industri makanan karena konsumen tidak saja menuntut makanan yang lezat dan nikmat, tetapi juga sehat dan bergizi. Nutrasetik dari perairan merupakan pilihan rasional dan menarik untuk industri makanan karena sumbersumber makanan dari organisme perairan laut maupun darat menyediakan berbagai komponen makanan fungsional yang dapat diperoleh dari sumbernya.

\section{REFERENSI}

Anonim, 2003 Mencari Obat Mujarab dari Laut, 
http://66.102.9.104/Search?q=cache:ze9W XbUlnj4J: www. Forek.or.id/detail.

Budiyanto AK, 2002. Dasar-Dasar Ilmu Gizi. Malang: Universitas Muhammdiyah Malang

Caraan, G.B., Lazaro, J.E., Concepcio, G.P., 1994, Biologycal Assays for Screening of Marine Sampels, Second Marine Natural Product Workshop, Marine Science Institute and Institute of Chemistry, University of the Philippines.

Limbong, D., Melumpi M, Mberato Y, Dosi F. 2012. Biostatistik Sidat Perak Danau Poso. Jurnal Riset Unkrit, Vol 1, No. 1, 2012 : $1-9$.

Napitupulu, R.J. 2011. Pengolahan Ikan Sidat. Modul Penyuluh Perikanan. Jakarta.
Rokhmin, D. 2003. Keanekaragaman Hayati Laut, Aset Pembangunan Berkelanjutan Indonesia. Penerbit PT Gramedia Pustaka Umum, Jakarta, 2003.

Soediro, Iwang. 1998. Warta Tumbuhan Obat Indonesia. Produk Alam Bahari dan Pemanfaatannya. Volume 4, Nomor 1. Jakarta: Kelompok Kerja Nasional Tumbuhan Obat Indonesia.Rahardja, P. dan M.Manurung, 2006. Teori Ekonomi Mikro : Suatu Pengantar. Lembaga Penerbit Fakultas Ekonomi UI. Jakarta. (Untuk buku teks) 